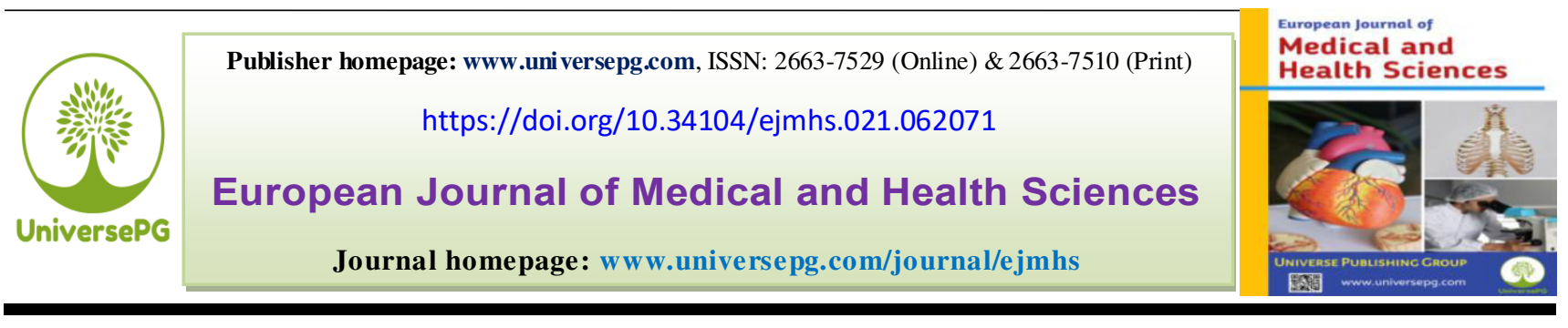

\title{
Assessment of Medical Waste Management Practices: A Case Study in Gopalganj Sadar, Bangladesh
}

\author{
Md. Rajib Hossain ${ }^{1 *}$, Md. Aminul Islam ${ }^{1}$ and Mehedi Hasan ${ }^{1}$ \\ ${ }^{1}$ Department of Environmental Science and Disaster Management, Bangabandhu Sheikh Mujibur Rahman Science and \\ Technology University, Gopalganj, Bangladesh. \\ *Corresponding author: rajib.esd@bsmrstu.edu.bd (Md. Rajib Hossain, Assistant Professor, Dept. of Environmental \\ Science and Disaster Management, Bangabandhu Sheikh Mujibur Rahman Science and Technology University, \\ Gopalganj, Bangladesh).
}

\begin{abstract}
At this time, waste may be a new concern that's generated and the management of waste is very important. The study was attended in one public hospital, seventeen private clinics and diagnostic centers, and two nongovernmental organizations at Gopalganj Sadar in Bangladesh from October to December 2019 where no rigorous estimation of medical waste generation is supported by the scientific way. This study reviews the current situation of medical waste management and practices in several clinics and hospitals. Medical solid waste could be a special style of waste that carries a high potential for infection and injury. The main purpose of the study is to understand the current management system of treated waste and therefore the treatment solid waste disposal system. A convenience sampling technique, field visits, and interviews with health personnel and staff were followed to gather data. The information was gathered through questionnaires target various aspects like waste segregation and collection, storage and transport, awareness in addition. No waste management and resource segregation system were found, the absence of relevant healthcare practical training in dealing with this waste properly. The municipalities aggregate the waste and get rid of it finally.
\end{abstract}

Keywords: Disposal, Gopalganj Sadar, Medical waste, Segregation, Assessment, and Waste management.

\section{INTRODUCTION:}

Hospital waste generally is understood as any quiet waste that's generated within the diagnosis, treatment, or immunization of individuals or animals or a hospital. From diagnosis monitoring and preventive, curative, or palliative activities within the sphere of veterinary and human medicine, medical wastes are raised (BAN and HCWH, 1999). Different types of waste are generated which result in the release of sharp objects, infectious wastes, chemical materials and radioactive wastes (Pruess et al., 1999). Medical wastes are infectious and unsafe which poses serious threats to environmental health in order that we require specific treatment and management before its final disposal (Hassan et al., 2008). The
World Health Organization (WHO) report and research phase have various estimates regarding the hazardous and nonhazardous components of medical waste, where around $85 \%$ of hospital wastes are nonhazardous, $10 \%$ hazardous (biologically infect-ious) and the remaining 5\% are pharma-ceuticals, toxic chemicals and radioactive wastes (Pruess et al., 1999). Medical waste has a serious risk for its arbitrary management to those who are involved wholly and partially with the management including doctors, nurses, sweepers, patients, hospital visitors and technicians (Massrouje, 2001; Becher and Lichtnecker, 2002). In developing countries like Bangladesh, health care is a major problem (Hossain et al., 2011). 
Lack of appropriate management and open dumping mix with household waste can cause environmental pollution. Wind from these dumps can even carry pathogens and dangerous materials. When sheep are permitted to graze on open wastes, there is a chance of harmful germs being reintroduced into the environment due to natural phenomena. Medical waste, therefore, poses a risk to individuals, communities and also the environment if not handled carefully (Akter et al., 1997; Uddin et al., 2014; Akter et al., 2005). Medical waste may well be a source of contamination and pollution to both humans and also the environment. Through direct contact or indirectly contaminating the soil, surface water of the land, and air, medical waste is capable of causing human diseases and illnesses (PRISM Bangladesh, 2005). Under the Environmental Protection Act, 1995, private clinic owners, governments and organizations (NGOs) are therefore increasingly indifferent to what the consensus among policymakers is crucial for a healthy environment in healthcare facilities. Due to its contagious and dangerous nature, waste management in medical is quite important. Management systems of waste are absent in both governmental and non-governmental healthcare facilities (Nessa et al., 2001). In the developing countries, it is dumped along with domestic waste because waste of medical is not given considerable attention (Almuneef and Memish, 2003; Patil and Pokhrel, 2005). However, in many countries are still disposed of treated waste properly. If they are implemented properly, they will end in better effects for both individuals and also the environment (Survey Report, Executive Summary 2012). Proper planning, fun- ding, administration and commitment at the policy level are significant factors for the right management of healthcare waste. Trained team handle many procedures connected to waste disposal such as transportation, segregation, reuse, etc., for effective management. Worldwide the medical waste is considered hazardous, therefore it should be treated accordingly (Ross, 2011).

The secure disposal of hospital waste has been ignored and the management is extremely bad in Bangladesh. Both governmental and organizational sectors do not seem to be watching out significantly for this problem. So, every day the matter is additionally increasing. Safe arrangement of medical waste could be a vital part of hospital management. But most healthcare institutions in Gopalganj Sadar is not following the right disposal system. But the range of hospital waste growing daily. The main objective of this research is to understand the medical waste management system and solid waste disposal system in Gopalganj Sadar.

\section{MATERIALS AND METHODS:}

Study Area - The Gopalganj is the city where the populations are increasing day by day for the general public university, industry and other job facilities. Gopalganj Sadar is located at $23.0167^{\circ} \mathrm{N} 89.8333^{\circ} \mathrm{E}$ which has 51, 630 households and a total area of $391.35 \mathrm{~km}^{2}$. Gopalganj Sadar had a population of 291,409 . Males constituted $50.73 \%$ of the population and females $49.27 \%$. The population density is 6874 per sq. $\mathrm{km}$ and $75.1 \%$ are educated people among them (BBS, 2013).

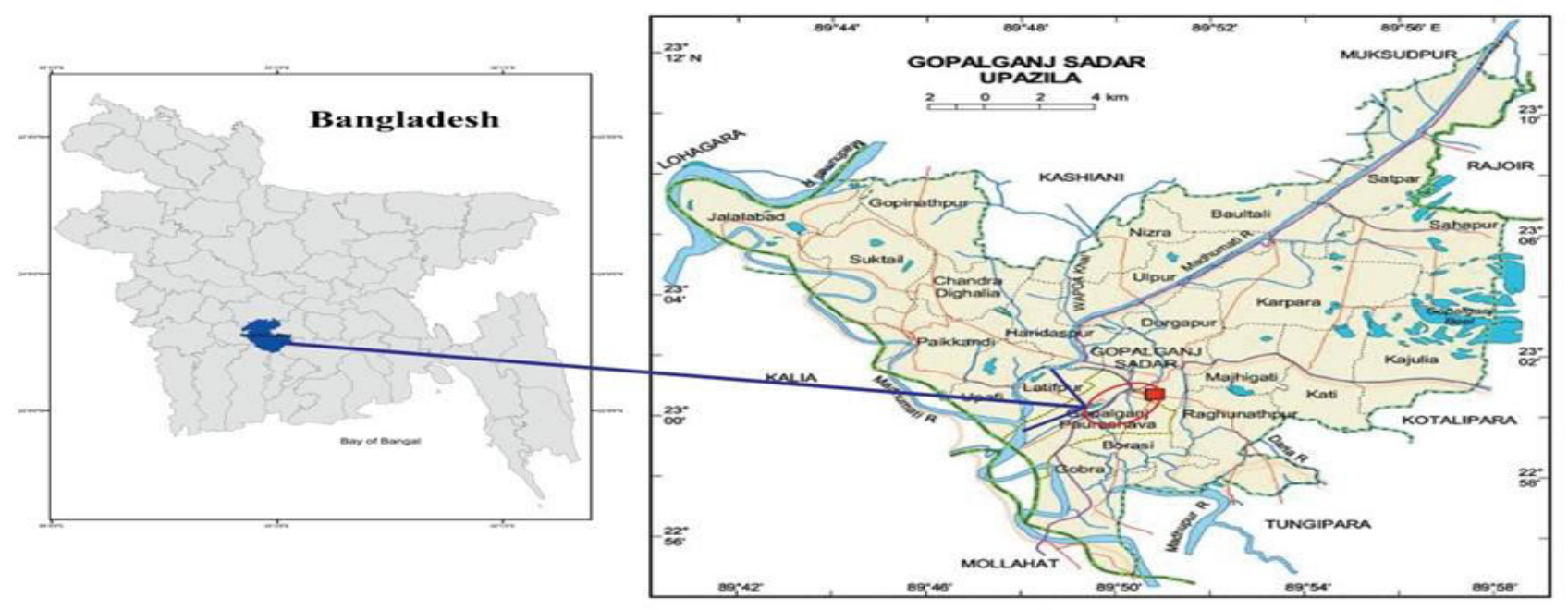

Fig 1: Map of Bangladesh indicating Gopalganj district and the study area Gopalganj Sadar marked by an oval shape in district map of Gopalganj. 
Selection of Healthcare Establishments - There are several types of healthcare centers like hospitals, clinics, maternity centers and pathological or diagnostic centers in Gopalganj. Among them, we visited 20 clinics and hospitals. The selected healthcare institutions were given below (Table 1).

Table 1: Name of the selected health care establishments/hospitals and clinics with sample size.

\begin{tabular}{|c|c|c|c|}
\hline SL. & $\begin{array}{c}\text { Name of } \\
\text { Hospital/Clinic }\end{array}$ & $\begin{array}{l}\text { Class of } \\
\text { hospital }\end{array}$ & $\begin{array}{l}\text { Number of } \\
\text { respondents }\end{array}$ \\
\hline 1 & Gopalganj sadar hospital & Govt. & 10 \\
\hline 2 & $\begin{array}{l}\text { Ajgor clinic and } \\
\text { diagnostic center }\end{array}$ & Private & 8 \\
\hline 3 & $\begin{array}{l}\text { Group clinic and } \\
\text { diagnostic center }\end{array}$ & Private & 8 \\
\hline 4 & $\begin{array}{l}\text { Labiba poly clinic and } \\
\text { diagnostic center }\end{array}$ & Private & 8 \\
\hline 5 & $\begin{array}{l}\text { Cure home clinic and } \\
\text { diagnostic center }\end{array}$ & Private & 7 \\
\hline 6 & Maloncho surgical clinic & Private & 6 \\
\hline 7 & $\begin{array}{l}\text { Shikderorthin clinic and } \\
\text { diagnostic center }\end{array}$ & Private & 6 \\
\hline 8 & Prottasha clinic & Private & 6 \\
\hline 9 & Nurgis clinic & Private & 6 \\
\hline 10 & Bhiyan clinic & Private & 6 \\
\hline 11 & Gopalganj nursing home & Private & 5 \\
\hline 12 & Bynodini clinic & Private & 5 \\
\hline 13 & Shandhani clinic & Private & 5 \\
\hline 14 & Jononi surgical clinic & Private & 5 \\
\hline 15 & Rabeya clinic & Private & 5 \\
\hline 16 & $\begin{array}{l}\text { Niramoy nursing home } \\
\text { and diagnostic center }\end{array}$ & Private & 5 \\
\hline 17 & $\begin{array}{l}\text { Unique clinic and } \\
\text { diagnostic center }\end{array}$ & Private & 5 \\
\hline 18 & $\begin{array}{l}\text { Adorsho clinic and } \\
\text { diagnostic center }\end{array}$ & Private & 4 \\
\hline 19 & Marie stopes Bangladesh & NGO & 5 \\
\hline 20 & Surjer Hashi clinic & NGO & 5 \\
\hline \multicolumn{3}{|c|}{ Total $=$} & 120 \\
\hline
\end{tabular}

Data collection - Many formal and informal methods have been used for collecting information. Random sampling criteria are used for data collection. This study was carried out based on available primary and secondary data. The primary data were collected through focus group discussion and a questionnaire survey. Total 120 questionnaire surveys were conducted for primary data from twenty health care establishments and almost all respondents are knowledgeable persons including the doctor, nurse, sanitary staff, manager and others. Before entering the hospital or clinic, the study team UniversePG I www.universepg.com was seeking the approval of the involved authorities of each medical hospital and clinic. Secondary data were gathered from relevant books, daily national newspapers, journals and websites.

Data Interpretation - Data obtained from the survey and the secondary sources were interpreted and processed for the analysis of the investigate.

Data Analysis - In order to analyze the information regarding the purpose of the study, the collected data has been analyzed by statistical software SPSS for graphical analysis and presentation. The average and percentage are also used for statistical analysis.

\section{RESULTSAND DISCUSSION:}

Recurrence format by population characteristics of respondents - The survey is conducted above 20 years, age groups. In the case of the study, the categories of respondents were divided into 21-25 years, 26-30 years, 31-35 years, 36-40 years, $41-45$ years, 46-50 years and more than 55 years. The age distribution of the surveyed is given below (Table 2). The Table 2 shows that $11.67 \%$ of respondents are 21-25 years, $15 \%$ are $26-30$ years, $20 \%$ are $31-35$ years, $23.33 \%$ are $36-40$ years, $18.33 \%$ are $41-45$ years, $6.67 \%$ are $46-50$ years and $5 \%$ of respondents are more than 55 years old. Gender identification is the most vital part of the survey.

Table 2: Population characteristics of the respondents $(n=120)$, their age, gender, marital status, religion shown in this table with percentage.

\begin{tabular}{|l|l|l|}
\hline \multicolumn{1}{|c|}{ Characteristics } & \multicolumn{1}{c|}{$\begin{array}{c}\text { No. of } \\
\text { Respondents }\end{array}$} & $\begin{array}{c}\text { Percentage } \\
(\%)\end{array}$ \\
\hline $21-25$ & 14 & 11.67 \\
\hline $26-30$ & 18 & 15 \\
\hline $31-35$ & 24 & 20 \\
\hline $36-40$ & 28 & 23.33 \\
\hline $41-45$ & 22 & 18.33 \\
\hline $46-50$ & 8 & 6.67 \\
\hline $55<$ or 55 above & 6 & 5 \\
\hline Sex & 52 & 43.33 \\
\hline Male & 68 & 56.67 \\
\hline Female & \\
\hline Marital Status & 85 & 70.83 \\
\hline Married & 35 & 29.17 \\
\hline Unmarried & 82 & 68.33 \\
\hline Religion & 38 & 31.67 \\
\hline Muslims & \\
\hline Hindu &
\end{tabular}


The table shows that $43.33 \%$ of people were male while $56.67 \%$ of people were female. Among them $70.83 \%$ are married and $29.17 \%$ are unmarried. Within the respondents, $68.33 \%$ Muslims and 31 . $67 \%$ are Hindu respectively (Table 2 ). In this study area hospital or clinic, the people of both religions live in harmony.

Categories of the Respondent's - The occupation pattern of any family indicates the living pattern or status of the respondents. The figure represents that, $14.17 \%$ are doctors, $27.50 \%$ nurses, $20.83 \%$ sanitary staff, $24.17 \%$ manager and $13.33 \%$ others (Fig 2).

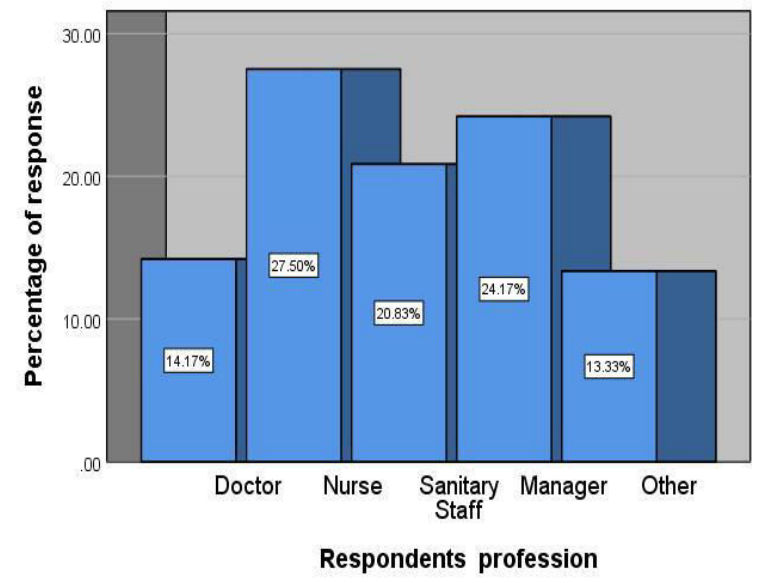

Fig 2: Percentage of respondents according to their profession.

Waste Management Knowledge of the Respondents - Training options of any hospital or clinic waste management approach are very important for the respondents. Most of the hospital and healthcare centers do not have knowledge of how to manage and deal with medical waste. Among the respondents, $32 \%$ staff have received training and $68 \%$ of respondents have not received any training to handle medical waste. Appropriate training must be done with hospital staff to develop an awareness of health, safety and environmental issues (Mohee, 2005). If the comprehension of medical waste removal technique is increased, medical waste management will be enhanced. In Iran $46.7 \%$ of hospitals assigned a person to be responsible for medical waste management (Askarian et al., 2004). Our study area includes 93.4\% have waste collection crew (Table 4) but most of them do not have proper training (Fig 3).

In developing countries, such as the USA, there are plans for effective training and education for all medical personnel related to medical waste management (Askarian et al., 2004).

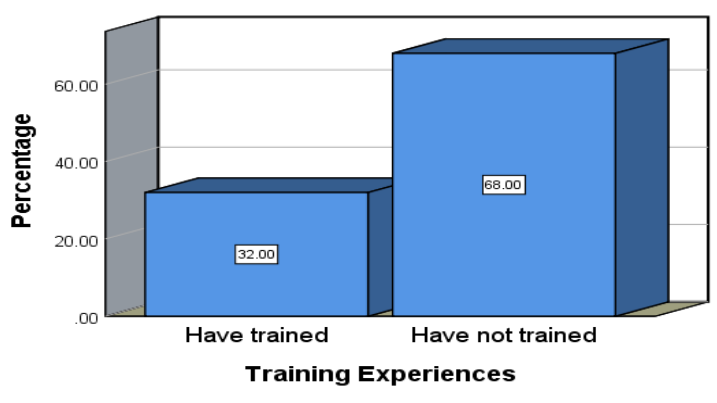

Fig 3: Percentage of respondents according to their experience in waste management.

Types of Wastes Generated from the Medical Center - The studied medical centers are generated various kind of waste which were collected by questionnaires from the respondents. Among studied medical centers, $17 \%$ are generated paper or foodstuff waste; $16 \%$ Sharpe waste (like a syringe, blades, etc.) and cotton, bandage; $14 \%$ saline bags; $13 \%$ blood and urine bags; $11 \%$ anatomic wastes or body parts (liquid, solid); 5\% Pharmaceutical wastes; 4\% pathological; $1 \%$ chemical waste; and $3 \%$ other kinds of waste (Fig 4). The healthcare facilities surveyed in Botswana had a combination of waste type $48.84 \%$ general waste, medical waste $39.39 \%$, sharps $13.13 \%$ which included food-related waste (Mmereki et al., 2017) while another research in Iran by Askarian reported $71.11 \%, 27.85 \%$, and $0.76 \%$ for general waste, Hazardous waste/infectious waste and sharps waste (Askarian et al., 2004), respectively.

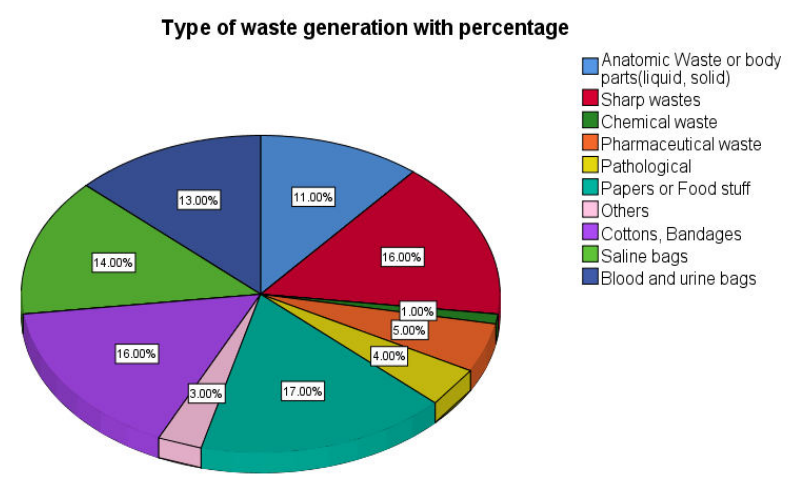

Fig 4: Percentage of the surveyed medical center based on various wastes generation.

Another study in Iran reported that Plastic and textiles were the first and second greatest contributors where Liquid was the third greatest contributor to hazardous-infectious waste and general waste, consisting of a substantial amount of food waste, plasticand paper/cardboard respectively (Hassan and Mohammad, 2009). 
Collection and Segregation of Hospital Waste Timing of Waste Collection - Among respondents, $55.5 \%$ said it was time to collect waste in the morning and $23.5 \%$ said it was noon and $21 \%$ said their waste is collected randomly and no specific time is maintained (Fig 5).

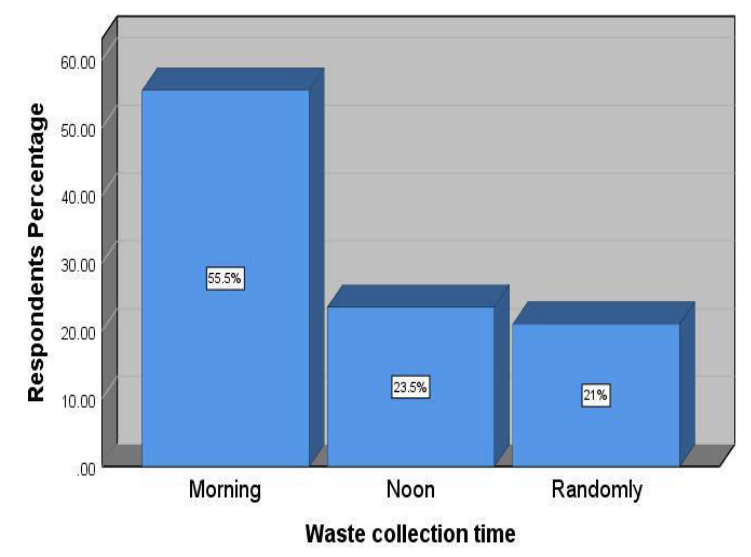

Fig 5: Percentage of the timing of waste collection from the surveyed medical centers.

China study by Yong repoted that disposal agencies arrange special trucks once every 1-2 days to collect medical waste from various hospitals (Yong et al., 2009). Following scientific standards, infectious waste in tropical areas can be stored in temporary storage areas for up to 24 hours in the hot season and 48 hours in the cold season (Pruess et al., 1999).

Onsite Segregation System - Onsite segmentation treatment is the most important step for waste management. In our national guideline, it is said that each one of the healthcare institutes should be segregated into six different color-coded bins. The survey found that any healthcare institutes did not segregate their waste in different bins. Only $4.17 \%$ respondent used four different color bins for waste segregation. A high percentage of respondents $(70.83 \%)$ used two bins to store waste (Table 3). So, they failed to segregate their waste and not followed our national guidelines.

Respondent's Response to the Collection and Segregation of Waste - This table (Table 4) represents that $93.4 \%$ say yes, they have a support crew for waste collection; $31.5 \%$ know or knowledgeable about the universal precaution rule of hospital waste management, $86.8 \%$ have a storage facility for generated waste; $64.5 \%$ say yes, that the storage is large enough to handle; $23.7 \%$ are handled waste temporarily before any treatment and disposal; $58 \%$ use the color-coding scheme all the time for waste segregation; $13.1 \%$ are injured while handling medical waste where most of their protective equipment is used.

Table 3: Onsite Segregation of waste in different HCEs of Gopalganj Sadar shown in percentage.

\begin{tabular}{|c|c|c|c|c|c|c|}
\hline & $\begin{array}{c}\text { Use of six bins } \\
\text { (perfect) }\end{array}$ & $\begin{array}{c}\text { Use of five bins } \\
\text { (Acceptable) }\end{array}$ & $\begin{array}{c}\text { Use of four bins } \\
\text { (Moderate) }\end{array}$ & $\begin{array}{c}\text { Use of three bins } \\
\text { (Below moderate) }\end{array}$ & $\begin{array}{c}\text { Use of two bins } \\
\text { (Bad) }\end{array}$ & $\begin{array}{c}\text { Only one bin } \\
\text { use (Terrible) }\end{array}$ \\
\hline $\mathrm{N}$ & 0 & 0 & 5 & 20 & 85 & 10 \\
\hline $0 \%$ & $0 \%$ & $0 \%$ & $4.17 \%$ & $16.67 \%$ & $70.83 \%$ & $8.33 \%$ \\
\hline
\end{tabular}

Table 4: Percentage of the respondent's response to the collection and segregation of waste.

\begin{tabular}{|l|c|c|}
\hline \multicolumn{1}{|c|}{ Question } & \multicolumn{2}{c|}{ Response (\%) } \\
\cline { 2 - 3 } & Yes & No \\
\hline Is there any support crew for waste collection? & $93.4 \%$ & $6.6 \%$ \\
\hline Are you knowledgeable about the universal precaution rule of hospital waste disposal? & $31.5 \%$ & $68.5 \%$ \\
\hline Do you have the storage facility for the generated waste? & $86.8 \%$ & $13.2 \%$ \\
\hline Is it large enough to hold the generated waste? & $64.5 \%$ & $35.5 \%$ \\
\hline Do you handle waste temporarily before treatment and disposal? & $23.7 \%$ & $76.3 \%$ \\
\hline Do you use the color-coding scheme all the time? & $58 \%$ & $42 \%$ \\
\hline Have you ever had any injuries while handling medical waste? & $13.1 \%$ & $86.9 \%$ \\
\hline
\end{tabular}

And also, they try to stay clean, so they always wash their hand with soap and water after removal of gloves, leave the work, taking breaks, before eating and get in touch with blood or other potentially infectious materials. In southern Brazil, about $85 \%$ hospitals have external storage areas for medical UniversePG I www.universepg.com waste management (Da Silva et al., 2005). Regarding the practice of isolation, a survey of China by Yong and others found that $73 \%$ of hospitals use segregation collections for all medical wastes, although $27 \%$ of hospitals still do not practice segregation collection (Yong et al., 2009). 
For segregation, $90 \%$ of hospitals used containers of different colors in Jordan (Abdulla et al., 2008). Medical waste is mixed with municipal waste which is discharged into the public drainage network (AlQudah, 2000; Jaffal, 2003) that could pose a public health risk to humans and a burden on the environment.

Knowledge about Medical Waste Management Knowledge is so much important for rising working capability and skill. For better hospital waste management staff knowledge about waste and its properties is important. The survey found that almost all respondents do not understand proper medical waste management. In our studied hospitals, only $14 \%$ know about it including 23\% partially know (Fig 6).

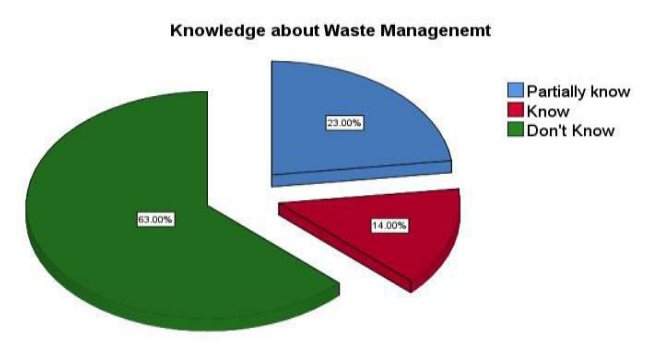

Fig 6: Percentage of the respondent according to their knowledge about the proper medical waste management.

Problems of the Prevailing Waste Management Identified by the Respondent - There were various kinds of the problem identified by the respondents in managing the correct waste management that is summarized in (Table 5). Most respondents mentioned lack of trained and adequate labor (18.33\%), absence of adequate dustbin (10\%), inadequate awareness (15\%), lack of observation (13.33\%), possibility of disease infection (10.84\%) and lack of an accurate segregation system $(7.5 \%)$ are the problems for this vulnerable condition of medical waste management. Some respondents also said that insufficient technology for waste treatment and disposal (8.33\%) and absence of proper guidelines (16.67\%) also serious problems for medical waste management.

Waste Collection and Disposal System - It is a disturbing circumstance that waste produced inside the emergency clinics was gathered without any segregation by unprotected, unaware and untrained cleaners. Our surveyed clinic had not practiced any UniversePG I www.universepg.com source-separation and there has no collection system and disposal system of their own.

Table 5: Problems of medical waste management in the study area identified by the respondents shown in percentage.

\begin{tabular}{|c|c|}
\hline Problems & $\begin{array}{c}\text { Response (\%) } \\
(\mathbf{n = 1 2 0})\end{array}$ \\
\hline Lack of trained and adequate & 18.33 \\
\hline Absences of adequate dustbin & 10 \\
\hline Inadequate awareness & 15 \\
\hline Lack of observation & 13.33 \\
\hline Possibility of disease infection & 10.84 \\
\hline $\begin{array}{c}\text { Lack of an accurate segregation } \\
\text { system }\end{array}$ & 7.5 \\
\hline $\begin{array}{c}\text { Insufficient technology for disposal } \\
\text { and waste treatment }\end{array}$ & 8.33 \\
\hline Absence of proper guideline & 16.67 \\
\hline
\end{tabular}

Generated wastes were gathered from the bed to the bed collection system that put away in a container or somewhere. The Gopalganj municipality collects it from there and dumps or dispose of it. Some of the clinics have their disposal system like incinerators and some of them dump in one place and waste collectors of the municipality collect waste. Surveyed clinics do not have any separate storage containers. The surveyed clinics, there have its crew to deal with waste and cleaning; they are hired by the clinic. But the majority of them are not trained or have no knowledge of management systems of medical waste. The solid waste is transferring to some other place by the municipalities and they manage to dispose of it. But the municipality disposes all the waste in one place and does treatment those separately.

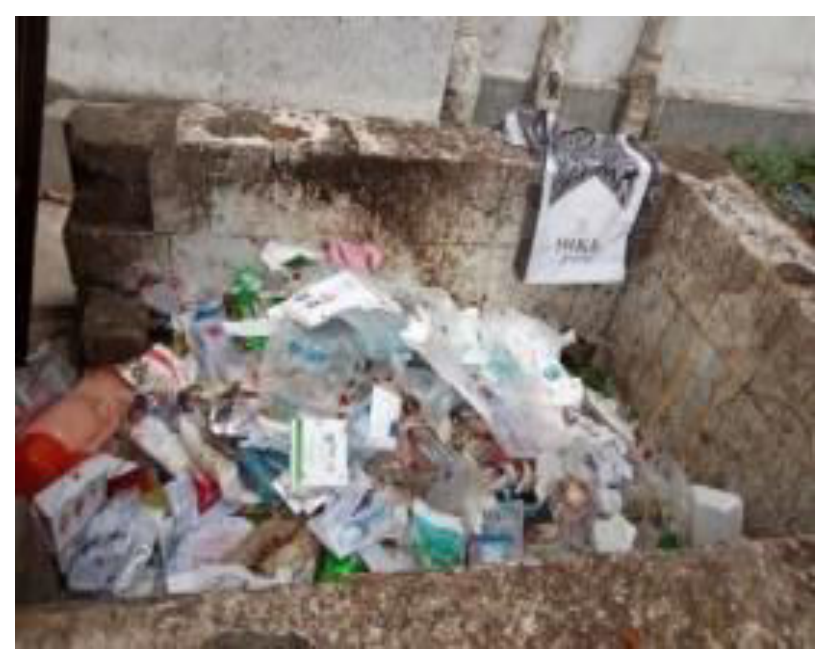

Fig 7: Temporary waste disposal site at the outside of one clinic among the studied clinics. 
A study at Dhaka in Bangladesh (Akter et al., 1999) reported that the waste collection was done using an open bucket (44.4\%) and a plastic bowl (23.9\%). Hospital wastes were disposed of in different places: a pit near the hospital (dig a hole), in a municipality

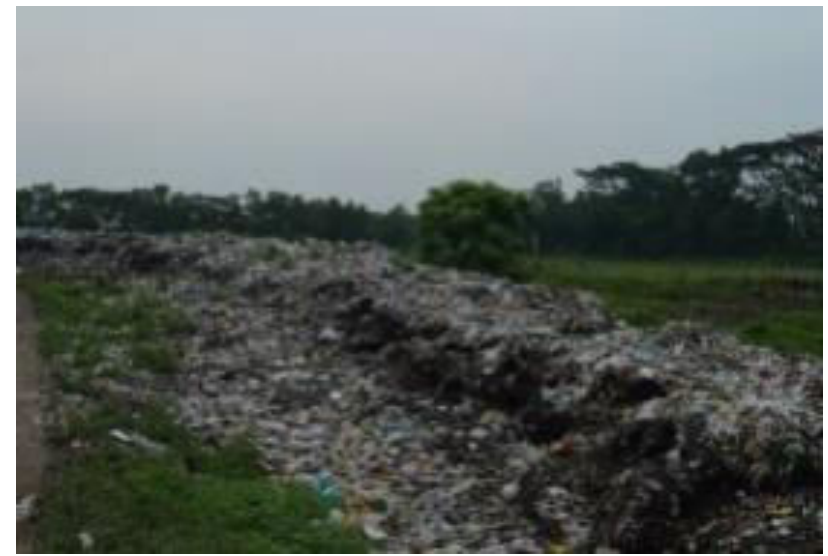

dustbin, an open field/roadside, or at the waterway. In Dhaka city, $59 \%$ of waste is dumped in municipal bins without any segregation (Akter et al., 1999). Present scenario of the waste management practice in Gopalganj Sadar has shown in the Fig $\mathbf{1 0}$.

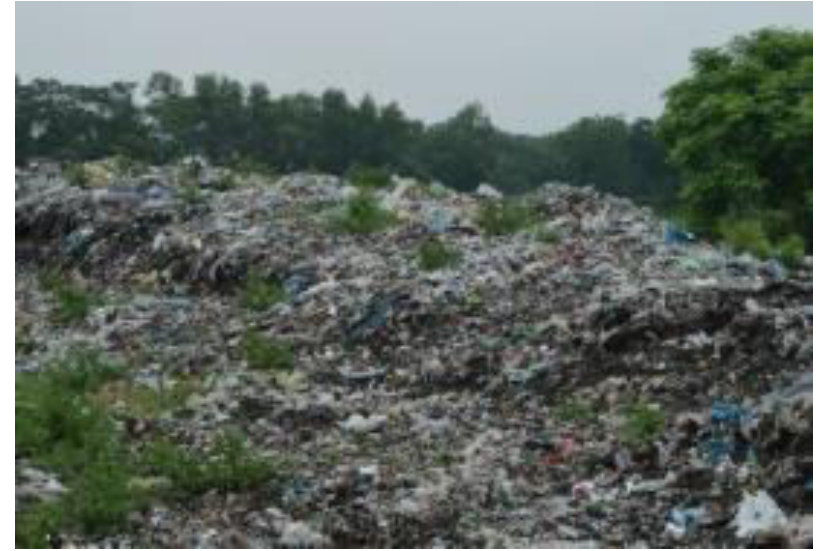

Fig 8: Final Disposal site of Gopalganj municipality at Gopalganj Sadar.

Methods of Treatment - This figure (Fig 9) represents that $58 \%$ of our total 20 studied hospitals and clinics use an autoclave for waste treatment while $21 \%$ hydroclave, $5 \%$ burning, $11 \%$ Dumping and $5 \%$ incineration respectively.

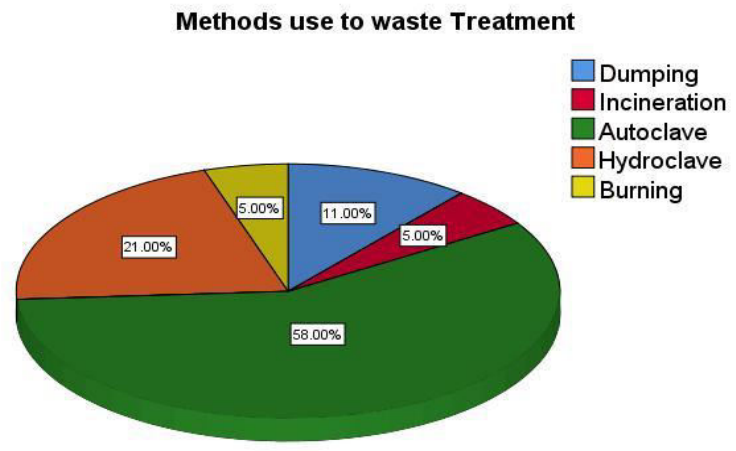

Fig 9: Method of treatment is normally used in the medical centers representing in percentage.

In Jordan, about $67 \%$ of hospital autoclave their extremely contagious medical waste before removal, while $14 \%$ of chemical disinfection hospital is used (Abdulla et al., 2008). There are many medical waste treatment methods, such as incineration, microwave sanitation, steam sterilization (or sanitation), chemical disinfection and disinfection with superheated steam (Jang et al., 2006). Only three disposal companies in Nanjing have applied combustion technology (Yong et al., 2009). But at present, major fractions of collected health waste are incinerated in developing countries (Diaz et al., 2005). With strict UniversePG I www.universepg.com environmental protection laws and regulations, combustion technology has received some condemnation from the government and researchers in recent years.

Recommended Management System - Proper waste management of medical is a new experience in Bangladesh and therefore Bangladesh Government is attempting to build up a modern way to cope with clinical waste appropriately. Prism Bangladesh (project in agriculture, rural industry, science and medicine), which is the reputed national NGO working in Bangladesh on medical waste management (Hassan et al., 2008). PRISM Bangladesh has created a system for carrying out hazardous waste (excluding radioactive waste) separately from each Healthcare Establishment (HCE) through recently designated vehicles for final dumping. PRISM Bangladesh is involved in relevant training on various HCEs for raising medical waste awareness and proper management at home which helps personnel to improve their knowledge. For proper waste management, it is important to segregate the waste at the source into appropriate color-coded bins. The Government of Bangladesh (GoB), recently introduced Color-coded bags. So that all HCEs could use color-coded bags for effortless identification and segregation of infectious and non-infectious medical wastes for proper handling. Waste handlers and everyone involved in the waste management process should be properly trained in proper segregation procedures to protect the public from potential 
injuries and diseases (Tsakona et al., 2007). So, the field of study should practice source segregation and the municipality of the Gopalganj Sadar should take the necessary steps to manage the hospital waste and make aware of individuals. If the field of study follows this system of waste management given in the Fig 11 then the situation can be better than the present scenario.

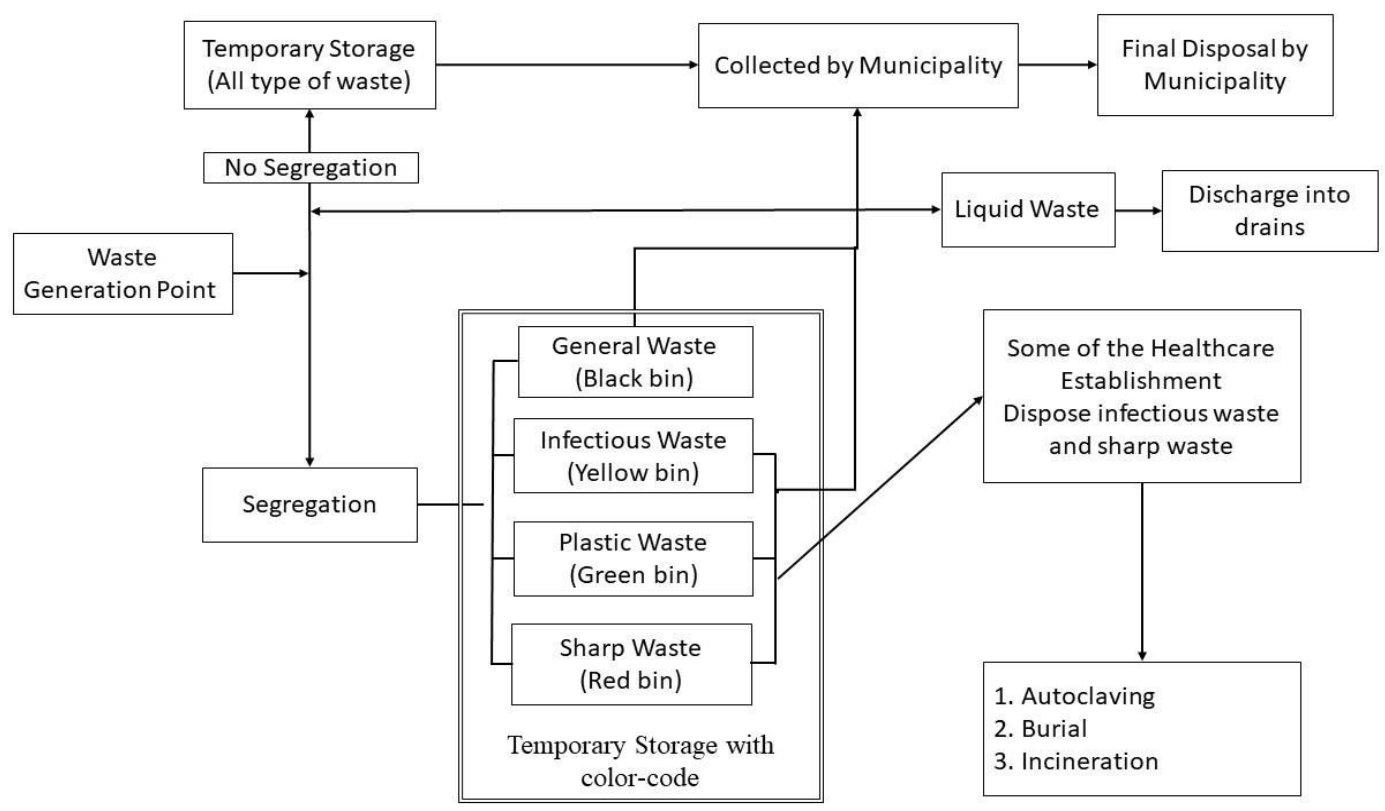

Fig 10: Present waste management practices in Gopalgonj Sadar.

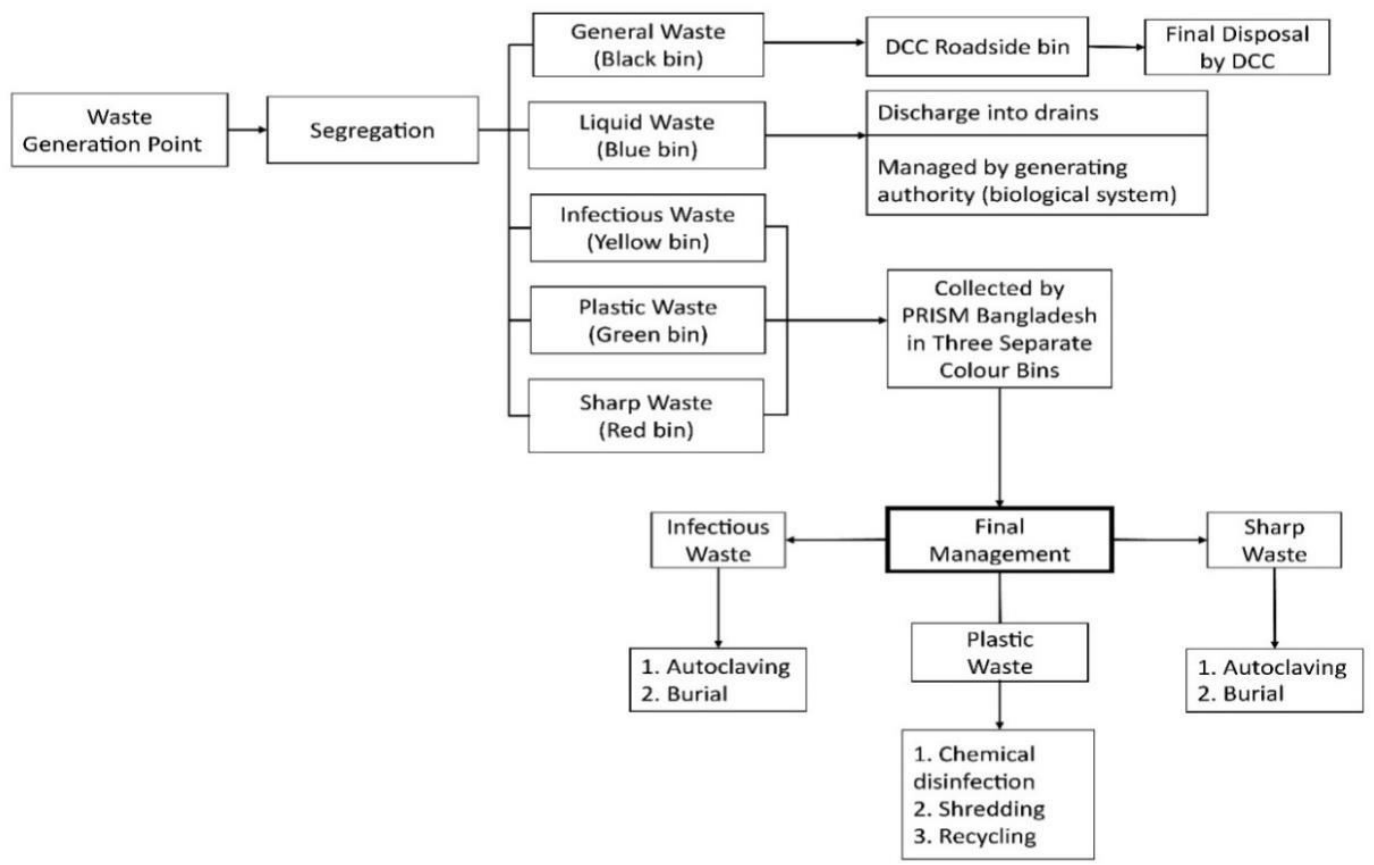

Fig 11: Existing waste management practice in some HCE Dhaka City (in-house waste segregation and final disposal) organized by PRISM Bangladesh.

This new system has been practiced since December 2005 (Hassan et al., 2008). This system is recommended for this study area

\section{CONCLUSION:}

Globally, Hospital Waste Management is one significant public health issue with a large environmental threat. Hospital wastes are highly hazardous and put individuals in risk of fatal diseases. The comprehension of hospital waste management and control strategies are important. Knowledge about medical waste and its management is extremely weak among senior staff and attendants. As they do not have enough information about hospital waste manage- 
ment and disposal so they could not handle it efficiently. The key to this study is to identify the gap in hospital waste management. This study raises people's awareness about management of medical solid waste and the knowledge that is important in our lives. In the future, researchers may conduct more detailed research on the awareness of nurses and other people, the situation of people who manage waste for collection. People in clinics and hospitals can improve waste management methods which will help to improve health safety.

\section{ACKNOWLEDGMENT:}

I thank all healthcare establishments and almost all respondents are including doctors, nurses, sanitary staff, managers and others for providing the appropriate data.

\section{CONFLICTS OF INTEREST:}

The authors declare that there is no conflict of interest regarding the publication of this paper.

\section{REFERENCES:}

1) Abdulla, Hani Abu Qdais, Atallah Rabi, (2008). Site Investigation on medical waste management practices in northern Jordan, Waste Management; 28, 450-458.

https://doi.org/10.1016/j.wasman.2007.02.035

2) Akter N, Kazi NM, Chowdhury MR. (1999). Medical Waste Disposal in Dhaka City: An Environmental Evaluation (Special Publication), Dhaka, Bangladesh: International Center for Diarrhoeal Disease Research (ICDDR, B).

http://citeseerx.ist.psu.edu/viewdoc/download?d oi=10.1.1.530.8191\&rep=rep1\&type $=$ pdf

3) Akter N, Rahman M, Sharmin L. (2005). Medical waste management at Rajshahi City Corporation Public-Private partnership model development. A collaborative effect on Medical waste management In Bangladesh (Baseline and status report). BRAC Research and Evaluation Division; BRAC Centre, 75 Mohakhali, Dhaka 1212, Bangladesh.

4) Akter, N., Acott, R. E., Sattar, M. (1997), June. Medical waste disposal at BRAC Health Centres: an environmental study. Research Reports (1997): Health Studies, 23, 151-179. http://hdl.handle.net/10361/13636

5) Almuneef, M. and Memish, Z. A. (2003). Effective medical waste management: it can be done. American Journal of Infection Control; 31(3):188-192. https://doi.org/10.1067/mic.2003.43

6) Al-Qudah O. (2000). Evaluation of medical waste disposal methods and their applications in Jordan. A Master's Thesis, Jordan University of Science and Technology, Irbdi, Jordan. https://doi.org/10.13140/2.1.3925.5364

7) Askarian, Mehrdad, Vakili, (2004). Results of a medical waste survey in private hospitals in Fars province, Iran. Waste Management; 24, 347-352.

https://doi.org/10.1016/j.wasman.2003.09.008

8) BAN and HCWH, (1999). Medical Waste in Developing Countries. An Analysis with a Case study of India and A critique of the Basel-TWG Guidelines, Basel Action Network (BAN) Secretariat Asian Pacific Environmental Exchange; $182739^{\text {th }}$ Ave. E., Seattle, WA. 98112 USA.

http://old.ban.org/subsidiary/clinical.html

9) BBS, (2013). Bangladesh Bureau of Statistics, District Statistics 2011, Gopalganj, PublishedDecember 2013.

https://www.amazon.com/District-Statistics-2

011-Bangladesh-Gopalganj/dp/9845190790

10) Becher, S. and Lichtnecker, H. (2002). Immunological aspects and affections of rubbish collectors caused by Bioaerosols. Journal of Occupational Health; 44(3):125-130.

https://doi.org/10.1539/joh.44.125

11) Da Silva CE, Hoppe AE, Ravanello MM. (2005). Medical wastes management in the south of Brazil. Waste Manag.; 25, 600-605. https://doi.org/10.1016/j.wasman.2004.03.002

12) Diaz LF, Savage GM, Eggerth LL. (2005). Alternatives for the treatment and disposal of healthcare waste in developing countries. Waste Management; 25, 626-637 https://doi.org/10.1016/j.wasman.2005.01.005

13) Hassan M.M., Ahmed S. A., Rahman K. A. (2008). Pattern of medical waste management: existing scenario in Dhaka City, Bangladesh. BMC Public Health; 8: 36. https://doi.org/10.1186/1471-2458-8-36

14) Hassan, Mohammad Mosaferi, (2009). Characterization of medical waste from hospitals in Tabriz, Iran. Science of Total Environment; 407,1527-1535.

https://doi.org/10.1016/j.scitotenv.2008.11.032 
15) Hossain, M. S.; Santhanam, A.; Norulaini. N. A. (2011). Clinical solid waste management practices and its impact on human health and environment A review. Waste Management, 31: 754-756. https://doi.org/10.1016/j.wasman.2010.11.008

16) Jaffal G. (2003). Biomedical waste management problems and strategic solutions. Unpublished Report Supervised by Dr. Yaseen Hayajneh, College of Medicine, Jordan University of Science and Technology, Jordan.

17) Jang, Yong -Chul, Lee, (2006). Medical waste management in Korea. J. of Environmental Management; 80, 107-115.

https://doi.org/10.1016/j.jenvman.2005.08.018

18) Massrouje, H. T. N. Nov. (2001). Medical waste and health care workers in Gaza governorates. Eastern Mediterranean Health J.; 7(6):1017-1024.

https://europepmc.org/article/med/15332744

19) Mmereki, Baldwin, Bazihan Li, (2017). Healthcare waste management in Botswana: storage, collection, treatment, and disposal system, Journal of Mater Cycles and Waste Management; 19, 351-365. https://doi.org/10.1007/s10163-015-0429-0

20) Mohee R. (2005). Medical wastes characterization in healthcare institutions in Mauritius. Waste Management; 25, 575-581. https://doi.org/10.1016/j.wasman.2004.10.003

21) Nessa K, Quaiyum MA, Barkat-e-Khuda, (2001). Waste Management in Healthcare Facilities: A Review. ICDDR; B Working Paper No. 144.

http://dspace.icddrb.org/jspui/bitstream/1234567 89/6609/1/wp144.pdf

22) Patil, G. V. and Pokhre1, K. (2005). Biomedical Solid Waste Management in an Indian Hospital: A Case Study, Waste Management; 25:592-599.

https://doi.org/10.1016/j.wasman.2004.07.011
23) PRISM Bangladesh, (2005). Survey Report on Hospital Waste Management in Dhaka City. Unpublished Report Dhaka: PRISM Bangladesh.

24) Pruess A, Giroult E, Rushbrook P. (1999). Safer Management of wastes from Healthcare Activities. World Health Organization (WHO), Geneva.

https://apps.who.int/iris/bitstream/handle/10665/ 42175/9241545259.pdf

25) Ross, D. E. (2011). Safeguarding public health, the core reason for solid waste management. Waste Management and Research; 29:779-80.

https://doi.org/10.1177/0734242X11416558

26) Survey Report, Executive Summary, (2012). Hospital Waste Management in Dhaka City Prism Bangladesh. www.prismbd.org/Hospital\%20waste\%20manag ement\%202005-05-2

27) Tsakona, M., Anagnostopoulou, E., Gidarakos, E. (2007). Medical waste management and toxicity evaluation: a case study. Waste management; 27, 912-920. https://doi.org/10.1016/j.wasman.2006.04.019

28) Uddin ME., Pulak M, Hossain MF. (2014). Isolation and characterization of proteases enzyme from locally isolated Bacillus sp., American J. of Life Sciences. 2(6), 338-344. https://doi.org/10.11648/j.ajls.20140206.12

29) Yong, Xiao Gang, Wang Guanxing, Zhou Tao, Jiang Dawei, (2009). Medical waste management in China: A case study of Nanjing. Waste Management; 29, 1376-1382. https://doi.org/10.1016/j.wasman.2008.10.023

Citation: Hossain MR, Islam MA, and Hasan M. (2021). Assessment of medical waste management practices: a case study in Gopalganj Sadar, Bangladesh. Eur. J. Med. Health Sci., 3(3), 62-71. https://doi.org/10.34104/ejmhs.021.062071 @ @ @ 